This new species is at once to be distinguished from $M$. globulus by (1) its well-marked gill-cuts, (2) the extreme narrowness of the median bare space and the consequent increase in the number of the tubercles, (3) the more spatulate character of the free end of the radius.

When its proportional measurements are compared with the specimen of an absolute diameter of 36 millim. ${ }^{1}$ we find the new species to be not so high, and to have the actinal, abactinal, and anal areas all proportionally a little larger.

$\begin{array}{ccccc}\text { Diam. } & \text { Height. } & \begin{array}{c}\text { Abactinal } \\ \text { area. }\end{array} & \begin{array}{c}\text { Anal } \\ \text { area. }\end{array} & \begin{array}{c}\text { Actino- } \\ \text { stome. }\end{array} \\ 38 & 22 & 7 \cdot 25 & 3 \cdot 5 & 12 \\ & {[57 \cdot 9]} & {[19]} & {[9 \cdot 2]} & {[31 \cdot 5]}\end{array}$

The numbers in brackets are the percentage values.

3. Contributions to the Anatomy of Passerine Birds.-Part IV. ${ }^{2}$ On some Points in the Anatomy of the Genus Conopophaga, and its Systematic Position. By W. A. Forbes, B.A., Prosector to the Society.

[Received February 28, 1881.]

As regards the true relationships of the genus Conopophaga considerable doubt has hitherto prevailed amongst systematic zoologists. By Sundevall ${ }^{3}$ it was placed amongst the Tyrannidæ, on account of its depressed beak and the nature of its tarsal scutellation. Messrs. Sclater and Salvin, in their valuable ' Nomenclator Avium Neotropicalium' ${ }^{4}$, followed Sundevall-the Conopophaginæ, consisting of the genera Conopophaga and Corythopis, therein forming the first subfamily of the Oligomyodian Tyrannidæ. All these authors, however, had overlooked the fact that Johannes Müller, in his classical memoir on the Voice-organs of the Passerinæ ${ }^{5}$, had described the syrinx of Conopophaga aurita, and had found it to be completely tracheophone, that of the Tyrannidæ having, of course, no such structure. Garrod was, no doubt, aware of Müller's results ; for in his proposed rearrangement of the Tracheophone Passeres ${ }^{6}$, he made the "Conopophagidæ" a distinct family, which he placed between the Dendrocolaptidæ and the Formicariidæ. No reasons, however, for the change were there given.

A few days ago Mr. Salvin called my attention to the fact that in a skeleton of Conopophaga melanops, lately acquired for the Cambridge

1 P. Z. S. 1880 , p. 435.

2 For Part III. see P. Z. S. 1880, p. 387.

3 Tentamen, p. 60 : Stockholm, 1872.

4 L.c. p. 41 : London, 1873.

5 Ueber d. Stimmorgane \&c., p. 39 : Berlin, 1847. Garrod's edition, p. 32.

6 P.Z.S. 1877 , p. 452. 
University Museum, the sternum presented four notches along its posterior margin, a very unusual condition in Passerine birds. This again drew my attention to the genus; and being fortunately the possessor of a specimen in spirit of Conopophaga lineata from Pernambuco, 1 have been enabled to confirm Mr. Salvin's discovery, as well as to make some other notes on the structure of this genus. As regards the sternum, it will be seen, from the drawing I now exhibit of that of Conopophaga lineata, to possess, as already stated, four

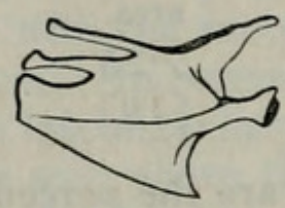

Sternum of Conopophaga lineata, of the natural size ; viewed, slightly obliquely, from the side.

notches, two on each side, on its posterior margin. Both are quite distinct; but the outer one is considerably the larger of the two, running up to near the base of the "costal process." The outer xiphoid process diverges considerably, so that there is a wide space between its termination and that of the internal one. This latter is terminally expanded and closely approximated, internally, to the body of the sternum, with only a very narrow cleft separating the ossified parts there. In other respects the sternum and its appendages are characteristically Passerine, there being a large bifurcated manubrium sterni, and a long, forwardly directed, costal process. The claricles are well developed, with a large hypocleidium and strongly expanded scapular ends. The carina sterni is well developed. The only other Passerine birds in which the sternum is four-notched are, so far as is yet known, sundry species of Pteroptochidæ (Pteroptochus albicollis, the species of Hylactes, and Scytalopus indigoticus). In Pteroptochus albicollis the two notches of each side are more nearly equal in size, and the internal xiphoid process is separated by a considerable interval from the body of the bone.

As regards the skull, Conopophaga is typically Passerine, not being in the slightest degree schizorhinal, as already stated by Garrod (l.c.). The vomer is broad and bifurcated. The maxillo-palatine processes are fairly long, spongy at the base, and recurved and dilated slightly apically, and do not articulate with the vomer, as is the case (e.g.) in Thamnophilus ${ }^{1}$. The "transpalatine" processes are well developed. In the macerated skull the external nares are divided into an anterior and a posterior opening, by the ossification of the alinasal cartilages. The same is the case in the species of Thamnophilus and in many other Passeres. I do not, however, attach much systematic importance to this character, as it occurs in Cymbirhynchus, and not

${ }^{1} C f$. Parker, Trans. Zool. Soc. ix. p. 313, pl. lvii. fig. 9. 
in Calyptomena, and in Hadrostomus, Tityra (just), and Lipaugus, but in none other of the Pipro-Cotingidæ. The only Tyrannine bird in which I have observed it is Arundinicola leucocephala.

From the character of its skull nothing very definite can be predicated of Conopophaga, except that it clearly has no relation to Furnariine forms. In its visceral anatomy, myology, pterylosis, and other characters I have detected no deviation from the ordinary Passerine structure. The typical arrangement of the tensor patagii brevis tendon is somewhat concealed, as in Pteroptochus and Hylactes (cf. Garrod, P.Z.S. 1876, p. 510), by the muscular fibres at the origin of the extensor metacarpi muscle. There is no trace of a vinculum in the deep flexor tendons of the foot. The artery of the leg is the sciatic. In the tarsi the anterior scutes, about six in number, extend round to the posterior margin exteriorly, leaving the internal plantar space covered by a smooth skin, with no signs of scutes or scutellæ. In its possession of an "exaspidean" ${ }^{1}$ tarsus, Conopophaga differs from all other forms of Tracheophonæ, and resembles Oxyrhynchus, the Tyrannidæ, and Pipridæ alone of Passerine birds.

The Tracheophone syrinx of Conopophaga aurita has been briefly described and figured by $\mathrm{Müller}^{2}$; and from that species $C$. lineata does not essentially differ. I find, however, that in this latter species the commencement of the tracheal syrinx is less abrupt than is depicted by Müller, the few preceding tracheal rings, particularly posteriorly, becoming gradually less and less deep as they approach the membranous part. The last tracheal ring is deeper and stronger than its predecessors, and is incomplete in the middle line behind. The first bronchial semiring is considerably stronger than the second one, and bears the processus vocalis, which extends upwards for about two rings. The last tracheal and first two bronchial semirings are less closely connected together than in Müller's figure. The tracheal syrinx forms a somewhat dilated tympanum. As regards the muscles, my observations agree with Müller's as to there being no intrinsic muscles, as the lateral tracheal muscle stops at the commencement of the membranous part of the trachea, from which place also the sterno-tracheales diverge.

This syrinx of Conopophaga does not exactly agree with that of any other Tracheophone group. In that it possesses processus vocales it resembles that of the Furnariidæ and Dendrocolaptidæ described by Müller (Pteroptochus, Hylactes, Formicarius, and Grallaria), and differs from Thamnophilus and Hypocnemis. In the absence of any intrinsic muscle it resembles Grallaria and $\mathrm{Hy}_{\text {- }}$ lactes, as described by Garrod, as well as Chamaza, Pteroptochus, and Formicarius. In Furnarius, Dendrocolaptes, \&c. this muscle is always present, and double. But in both Grallaria, Hylactes, and the others the sterno-tracheales muscles arise from the end of the vocal process. In Conopophaga, on the other hand, they leave the trachea before reaching that process.

1 As defined by Sundevall, l.c. p. 57.

2 L.c. p. 39, pl. vi. fig. 12 . Garrod's ed. p. 32. 
The peculiarity, therefore, of its sternum, when taken with its tarsal scutellation and peculiar syrinx, seems to demand that, as has already been proposed by Garrod, the genus Conopophaga ${ }^{1}$ should form a primary division of the Tracheophone Passeres, which may be defined as follows :-

Conopophagida.-Tracheophonine Passeres, with a holorhinal skull and four-notched sternum, an exaspidean tarsus, and a syrinx with no intrinsic muscles, and with the sterno-tracheales not attached to the processus vocales.

As regards the possession of a four-notched sternum by these birds and the Pteroptochidæ, I am not inclined to consider it in any way a primitive character, but rather as an instance of a simple modification having been independently acquired in different groups of birds (many parallel cases might be given). The Tracheophonine syrinx must, without doubt, be regarded as a modification of some Haploophonine form ${ }^{2}$; and in all these last birds, as in the still less specialized Eurylæmidæ, the sternum has the typical form with but two notches. On the other hand, the similarity of form of the sternum in the Pteroptochidæ and Conopophagidæ may very probably indicate that these groups may both have sprung from some common stock which had already developed a peculiar sternum.

\section{Note on the Generic Name Hypherpes.}

By Alfred Newton, M.A., F.R.S., \&c.

[Received March 15, 1881.]

My attention having been called by a note in the ' Zoological Record' (xvi. Aves, p. 28) to the prior use in entomology, by the Baron Chaudoir (Büll. Mosc. 1838, p. 8), of the generic name Hypherpes, conferred by me some years ago (P. Z. S. 1863, p. 85) on a bird discovered in Madagascar by my brother, I beg leave to substitute for the latter the name Hypositta ${ }^{3}$, and hope that this curious form will henceforth be known as Hypositta corallirostris.

1 Corythopis has not yet been anatomically examined; by Sundevall it is placed near Formicarius. It is therefore nearly certain to be Tracheophonine, and is probably really closely allied to Conopophaga.

2 Garrod, P. Z. S. 1876 , p. 517.

3 Th. vं $\pi \dot{o}, s u b ; \sigma i \tau \tau \eta$, Sitta. 


\section{$2 \mathrm{BHL}$ Biodiversity Heritage Library}

Forbes, W. A. 1881. "Contributions to the Anatomy of Passerine Birds.-Part IV. On some Points in the Anatomy of the Genus conopophaga, and its Systematic Position." Proceedings of the Zoological Society of London 1881, 435-438. https://doi.org/10.1111/j.1096-3642.1881.tb01298.x.

View This Item Online: $\underline{\text { https://www.biodiversitylibrary.org/item/96698 }}$

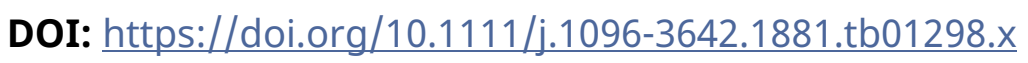

Permalink: https://www.biodiversitylibrary.org/partpdf/73296

\section{Holding Institution}

Natural History Museum Library, London

\section{Sponsored by}

Natural History Museum Library, London

\section{Copyright \& Reuse}

Copyright Status: Public domain. The BHL considers that this work is no longer under copyright protection.

This document was created from content at the Biodiversity Heritage Library, the world's largest open access digital library for biodiversity literature and archives. Visit BHL at https://www.biodiversitylibrary.org. 